\title{
BIKE LANE DESIGN FOR BICYCLISTS AND BIKE SHARING IN BANDUNG CITY
}

\author{
Widyarini Weningtyas*, Qiranawangsih Aulia, Lestari H. Adriani, Arbie Nurlayla \\ Faculty of Civil and Environmental Engineering, Institut Teknologi Bandung, Bandung, 40132, Indonesia
}

(Received: January 2015 / Revised: March 2015 / Accepted: April 2015)

\begin{abstract}
Cycling is now growing in Bandung City, Indonesia. One of the popular programs is bike sharing which was established in 2012. Recently, the bike sharing program has revealed a plan to develop bike stations and bike lanes. Thus, the bike lane plan needs to be adjusted with the Indonesian Design Standard for Bike Lanes. The standard takes into account physical characteristics of the roads/streets. It was found that most of the roads/streets on the list are not suitable for bike lanes; only 42 out of 151 are qualified. This means in order to encourage cycling activities, although it is not included in bike sharing program, the physical characteristics of roads/streets and sidewalks need to be developed.
\end{abstract}

Keywords: Bike Lane, Bike Sharing, Cycling, Roads/streets Characteristics

\section{INTRODUCTION}

The presence of sustainable public transport is getting more and more important in today's life. The statement is supported by the fact that, in some developing countries, bicycles have become more popular than ever before, especially for young adults. A survey in Bandung illustrated in Figure 1 shows that about $47.42 \%$ of the bike users are aged between 17 to 25 years old. These data were taken from a bike-rent users survey in 2012.

Cycling is one way of moving efficiently in the city with low carbon emissions and low costs. Bandung City has a cycling program called bike sharing as a new form of ecofriendly public transportation. Bike sharing is also intended to be a feeder for other public transportation modes in the city. This program is considered as one of the public transportation modes which is expected to reduce the number of motorized vehicles such that the traffic and emissions in the city may be decreased. It also will affect noise pollution and people mobility. In addition, people can be healthier, happier, and have a higher level of productivity. Bike sharing also contributes to the increase in the livability index of a city that implements the program.

Bike sharing was first introduced in 28 July 1965 in Amsterdam, the Netherlands (DeMaio, 2009). The program was not successful. Inappropriate behavior patterns occurred with the shared bikes; they were being claimed as private bikes or abandoned in the river. This was known as The $1^{\text {st }}$ Generation of Bike-sharing. The next improvements which took place in Denmark were in 1991, this program were called The $2^{\text {nd }}$ Generation (DeMaio, 2009). It did not go so well either, bikes were being stolen, even though their ownership had been formalized with bike stations and a non-profit organization as their operator.

The $3^{\text {rd }}$ Generation was on 1996 at Portsmouth University, England (DeMaio, 2009). It grew slowly until 2005 when a bike sharing program called 'Velo'v' was introduced in Lyon, France. 
There were 1,500 bikes and 15,000 bike share members. Learning from Lyon, Paris also launched its own bike-sharing program called 'Velib' with 7,000 bikes, which then expanded to 23,600 bikes in the city and suburbs (DeMaio, 2009).

All these three generations have different technological applications. The first ones were just ordinary bikes; the second generation was more well-ordered with stations and a formal operator; then the third generation was smartened up with a variety of technological improvements, including electronically-locking racks or bike locks, telecommunication systems, smartcards and fobs, mobile phone access, and on-board computers (DeMaio, 2009). Bike-sharing in cities in South East Asia is less popular, possibly because of the combination of the massive promotion of private cars and motorcycles, the lack of bicycling habits and technology, and also there are no supportive rules which assure bicycle user safety precautions.

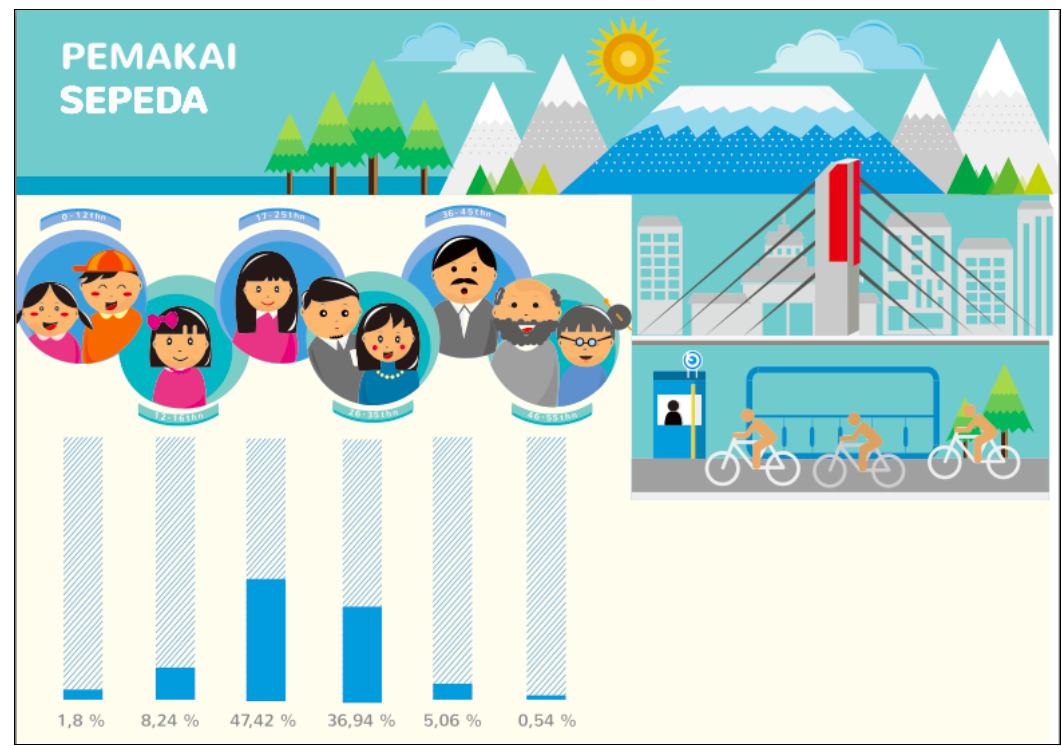

Figure 1. Bike User Percentage (The Figure Is In Indonesian)

Source: Research by Banopolis

Started in October 2011, the Mayor of Bandung City Ridwan Kamil, initiated the implementation of a bike sharing program in Bandung. The program started to operate in June 2012 with a very simple system and was funded by local residents. In two years the program succeeded in enhancing the promotion of the bike as an eco-friendly mode of public transportation, which can also be used for tourism purposes.

The bike sharing system in Bandung is claimed to be the first bike sharing system in Indonesia. It is aimed to be a sustainable public transportation which plays an important role as part of a feeder system for other transportation modes. Research on Bike sharing system in Bandung is being conducted. The study includes the formulation of a mechanical and electrical system, the design of the bikes and the determination of station locations along with the formulation of the wayfinding and signage strategy. Bike sharing system must be prepared appropriately to support the original purpose of Bike sharing development as an element of public transport in Bandung. The most important thing is to establish a cycling culture. Enhancement and establishment of a cycling culture is considered the most difficult task to do since the culture might influence people's lifestyle and it has to be supported with adequate systems.

In order to have a comprehensive system, the Bandung Bike sharing also needs infrastructure support with facilities such as bike lanes. On collector and arterial roadways, 
bike lanes or wide curb lanes can encourage people to ride a bike rather than drive for short trips and moderate distances (Pennsylvania Department of Transportation and New Jersey Department of Transportation, 2008). Bike lanes are the ideal facility for accommodating basic bicyclists. By designating a space only for bicyclists, they give bicyclists a measure of comfort that motorists will not drive into their path of travel. They serve to advise motorists of the possible presence of bicyclists. The presence of bike lanes encourages bicyclists to separate themselves from parked cars more than they otherwise might, reducing the possibility of being "doored." (Van Houten \& Seiderman, 2005). Cycling lanes, when protected from cars, encourage riders who may be intimidated by traffic, and the inclusion of signage giving bikes right-of-way helps remind drivers to share the road (ITDP, 2014).

Sometimes bike lanes can be installed as the valued by-product of a "road diet" treatment, in which a four-lane roadway is converted into two through-lanes with a two-way left-turn lane and two bike lanes. The road diet - known as removing and/or narrowing travel lanes - is one of the most common traffic calming practices for arterial and collector roads. In 2005 in New Jersey, Ocean City narrowed West Avenue, an arterial, from four lanes to three lanes and added bike lanes and a wide median strip. Installed for a trial period on six blocks, the residential response was so positive that the City extended the road diet treatment to two miles (Huang, Stewart, \& Zegeer, 2002). The popularity of road diets can be explained by their ability to lower speeds, improve safety, and add room for non-motorized users. A study for the Iowa Department of Transportation of 15 road diets documented a reduction in crash rates of 19\%, while a study of road diets in the Seattle area found an average crash reduction of $29 \%$. A review of 14 road diet treatments across the country indicate that eight resulted in speed reductions ranging from 1 to $5 \mathrm{mph}$, although no notable decreases were seen in six of the treatments. Road diets are particularly effective in calming aggressive motorists, since they are required to queue up in a single lane, often behind more patient motorists. (Kueper, 2007)

Table 1. Cycling Infrastructure Implemented Alongside Bike-share Systems

\begin{tabular}{ll}
\hline City & \multicolumn{1}{c}{ Bike Infrastructure With Bike-share System } \\
\hline Guangzhou, China & 46 Kilometers of segregated bike lanes \\
Paris, France & 68 kilometers of segregated bike lanes, in addition to 371 \\
& existing kilometers \\
London, United Kingdom & 37.8 kilometers of 4 cycle superhighways \\
Barcelona, Spain & 150 kilometers of segregated bike lanes \\
Boston, United States & 80 kilometers of segregated bike lanes (Kaiser, 2012) \\
Rio de Janeiro, Brazil & 300 kilometers of physically segregated (ciclovias), \\
& painted lanes (ciclofaixas) and signalized shared routes \\
& (either with either traffic or pedestrians) \\
\hline
\end{tabular}

Source: (ITDP, 2014)

In Bandung City, the plan to develop bike lanes is being conducted by the Bandung City Agency of Transportation. Bike lanes in Bandung will be provided both for the Bike sharing users and private bike users. Thus, the system should be integrated to meet the goals of people's changing lifestyles, establishing a cycling culture, and sustaining an eco-friendly transportation system. 


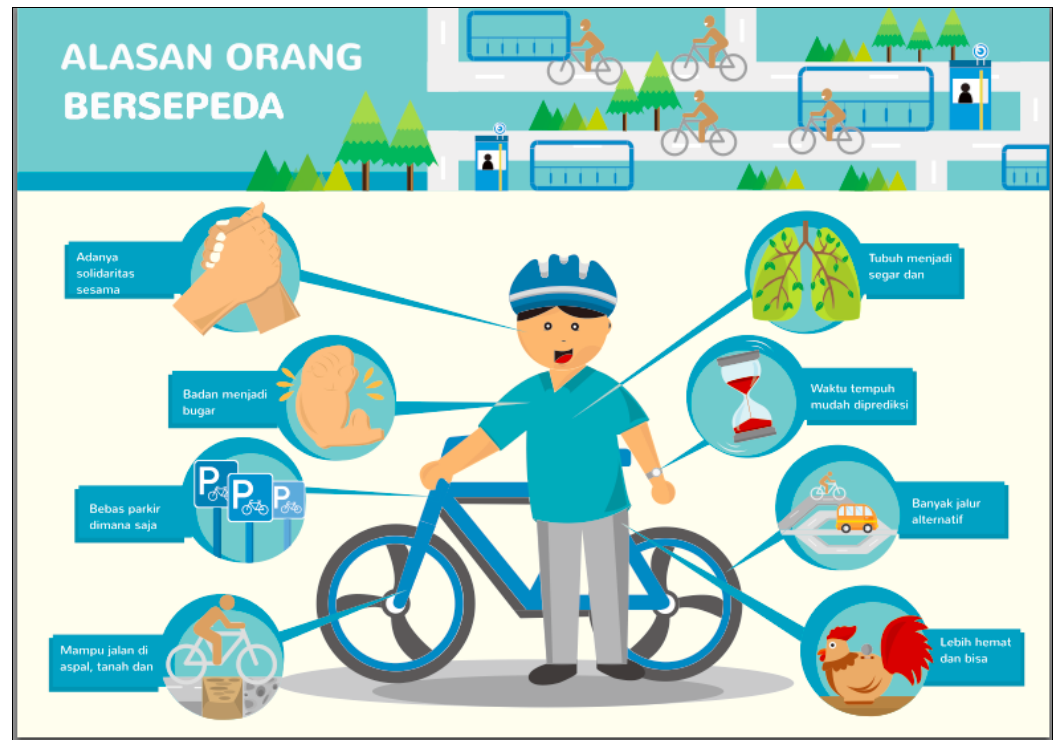

Figure 2. The Advantages of Using Bicycle (The Figure is in Indonesian) Source: Research by Banopolis

\section{OBJECTIVES}

The objectives of this study is to:

1. Conduct a comprehensive study about bike lanes.

2. Review potential locations (roads/streets) of bike lanes in Bandung City.

3. Conduct an infrastructure audit for bike lane types in Bandung City to determine from road and street classification and geometrical and topographical conditions.

\section{METHODOLOGY}

In order to support cycling activity in Bandung City, a comprehensive study about bike lanes is needed. This paper reviewed potential locations (roads/streets) of bike lane in Bandung City. Roads and streets characteristics will affect the bike lane type. Therefore, it is important to determine bike lane specification on each one of the roads and streets before deciding on the bike lane type. There is also a limitation for the minimum width of the roads, which is stated in Table 2. There are 151 roads and streets planned to have bike lanes. Each type of road/street does not always have a continuous road function and/or classification.

Table 2 Minimum Width of Road by Function and Classification

\begin{tabular}{lc}
\hline Road Function and Classification & Min. width $(\mathrm{m})$ \\
\hline Primary Arterial & 11 \\
Primary Collector & 9 \\
Primary Local & 7.5 \\
Primary Surroundings & 6.5 \\
Secondary Arterial & 11 \\
Secondary Collector & 9 \\
Secondary Local & 7.5 \\
Secondary Surroundings & 6.5 \\
\hline
\end{tabular}


Table 3. Bike Lane Type Plan based on Road Function and Classification

\begin{tabular}{lccc}
\hline $\begin{array}{c}\text { Road Function and } \\
\text { Classification }\end{array}$ & Highway & Middle Road & Small Road \\
\hline Primary Arterial & A & A & A \\
Primary Collector & A & A & A \\
Primary Local & C & C & C \\
Primary & C & C & C \\
Surroundings & & & \\
Secondary Arterial & A/B & A/B & A/B \\
Secondary Collector & B/C & B/C & B/C \\
Secondary Local & B/C & B/C & B/C \\
Secondary & B/C & B/C & B/C \\
Surroundings & & &
\end{tabular}

Source: Ministry of Public Works, 2013

Notes:

$\mathrm{A}=$ Bike lane on the road with curb

$\mathrm{B}=$ Bike lane on sidewalk

$\mathrm{C}=$ Bike lane on the road without curb

The next steps are explained in the flowchart shown in Figure 3.

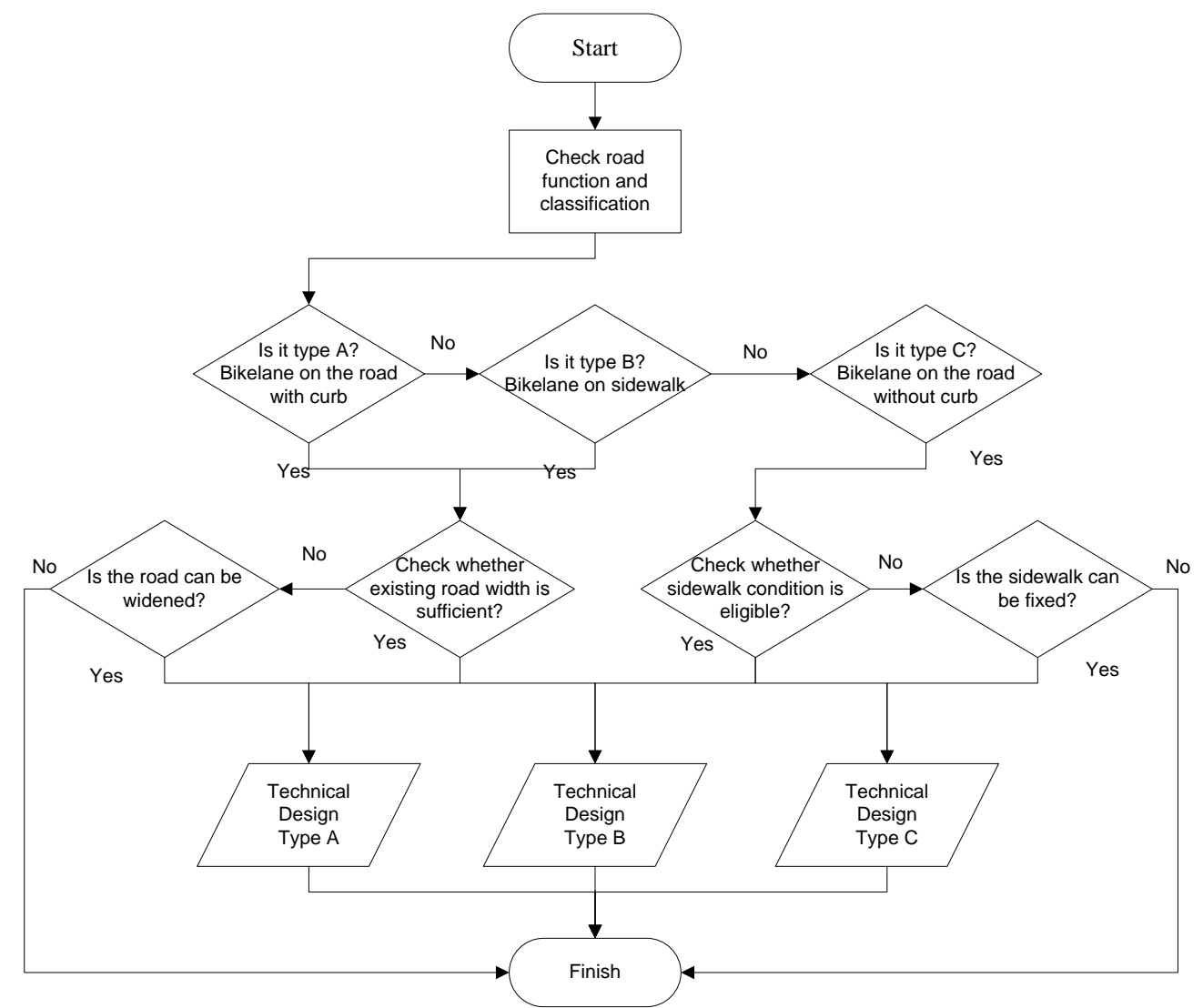

Figure 3. Bike Lane Classification Flowchart

(Source: Ministry of Public Works, 2013) 


\section{GEOGRAPHICAL INFORMATION}

Bandung City is one of big cities in the West Java Province as well as the capital city of the West Java Province. Its coordinates are $107^{\circ}$ east and $6^{\circ} 55^{\prime}$ south. This city is geographically located in the center of West Java. Bandung is one of the most favorite destinations for tourists due to its beautiful scenery, fresh air and the presence of many highly developed institutes. As a capital city of West Java, Bandung plays an important role to support social, economic and governmental activities. Bandung has a high level of various economic activities, such as services and trading. Consequently, Bandung faces inevitable problems related to basic infrastructure supply, such as housing, clean water, energy, transportation, and communication. This is worsened by degradation of the city environment.

Transportation is one of Bandung's most serious problems. Bandung's roads are generally congested during the morning and afternoon peak commuting hours. Currently, its total $\mathrm{km}$ road length is $932,701 \mathrm{~km}$ (www.bps.go.id, 2015). Because of limited land available for public use, it is therefore difficult to build new roads. Thus, enhancing public transportation can be considered as one potential solution to address this problem.

In 2013, the population of Bandung reached to 2,483,977 people. Over the past decade, the Bandung population growth has increased rapidly. Table 1 shows population growth in Bandung City.

Table 4. Population in Bandung City, 2004-2013

\begin{tabular}{lc}
\hline Year & Population \\
\hline 2004 & $2,239,757$ \\
2005 & $2,303,913$ \\
2006 & $2,338,359$ \\
2007 & $2,372,234$ \\
2008 & $2,400,340$ \\
2009 & $2,427,697$ \\
2010 & $2,394,873$ \\
2011 & $2,437,874$ \\
2012 & $2,461,931$ \\
2013 & $2,483,977$
\end{tabular}

Source : West Java Statistic Data Center (2004-2012) and Bandung Statistic Data Center (2013)

\section{BIKE LANE AND BIKE SHARING STATION PLANS IN BANDUNG}

The AASHTO Guide for the Development of Bicycle Facilities defines a bike lane as "a portion of a roadway which has been designated by striping, signing, and pavement markings for the preferential or exclusive use of bicyclists."(1998).

Bike lane and bike sharing station plans, which are being developed, have created a planning map. This map contains information about the exact location of the bike sharing station plan complemented with a bike lane route plan. This plan was made based on cycling activity needs and cycling coverage areas in schools and universities, commercial areas, office areas, public areas, and residential areas. Thus, an adjustment should be made to comply with roads/streets characteristics. 


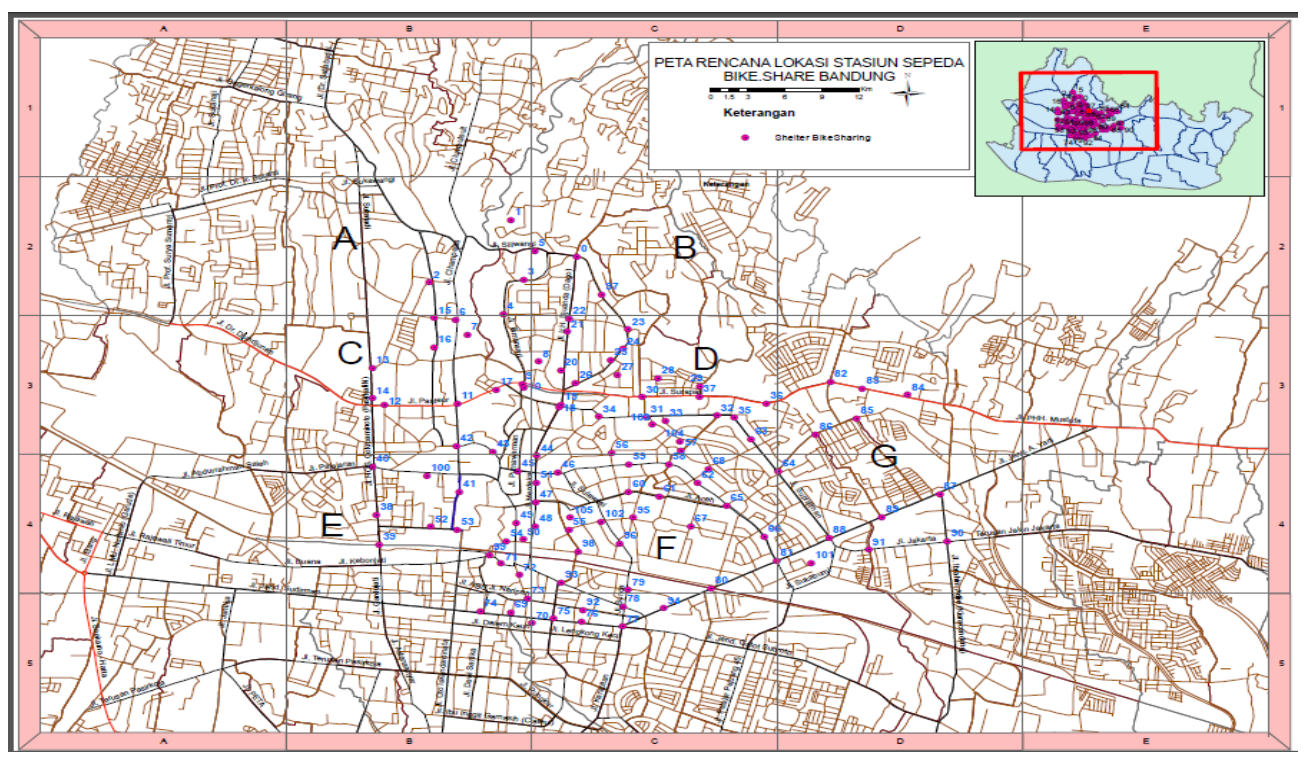

Figure 4. Bike Station Site Plan

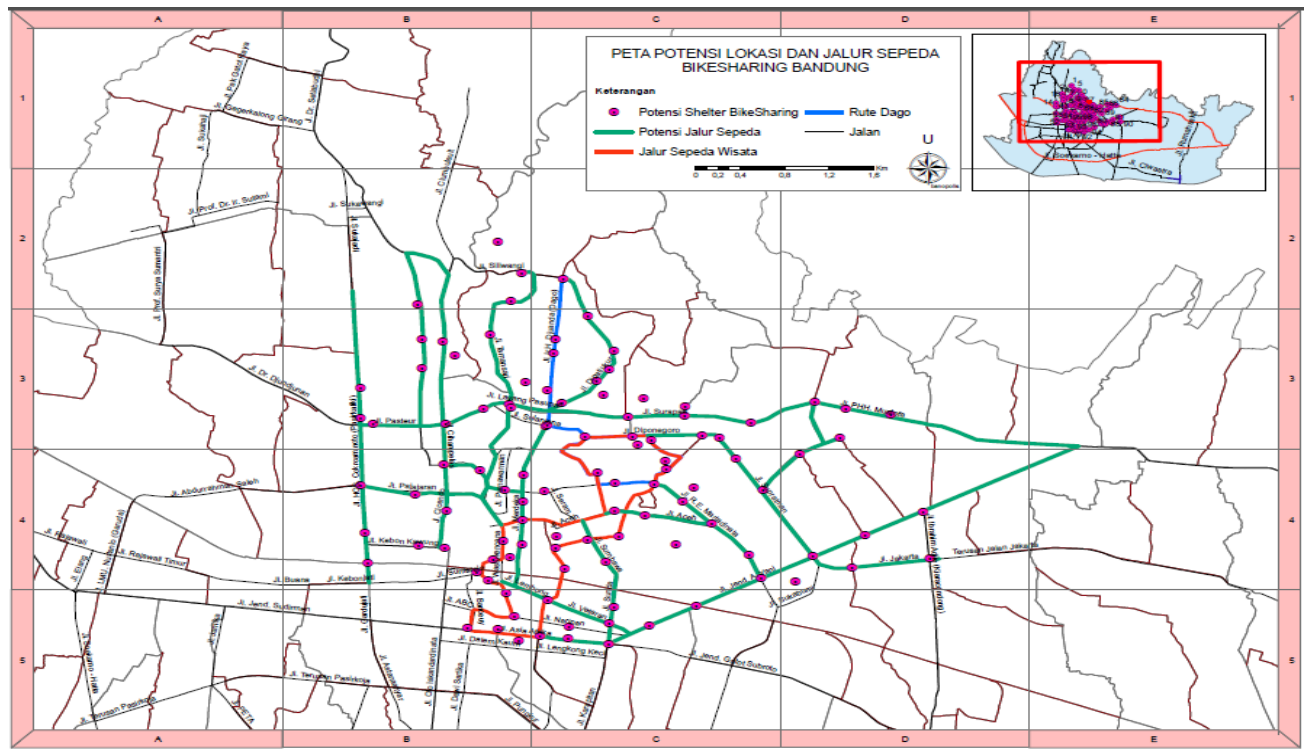

Figure 5. Bike Lane Plan

\section{BIKE LANE TYPES}

The bike lane standard in Indonesia are based on physical characteristics of existing roads/streets. Bike lane types are divided into three types, namely: Type A for an on-street lane with a curb lane, Type B for an on-sidewalk lane, and Type $C$ which is an on-street without a curb lane. All these lane designs depend on road function and road class of the desired bike lane. A guideline titled, "Pedoman Perancangan Fasilitas Lajur dan Jalur Sepeda" (Ministry of Public Works, 2013) explains clearly about how to design a bike lane.

The first step of the design is to identify road function and road classification where the bike lane will be located. This is shown in Table 3 . 

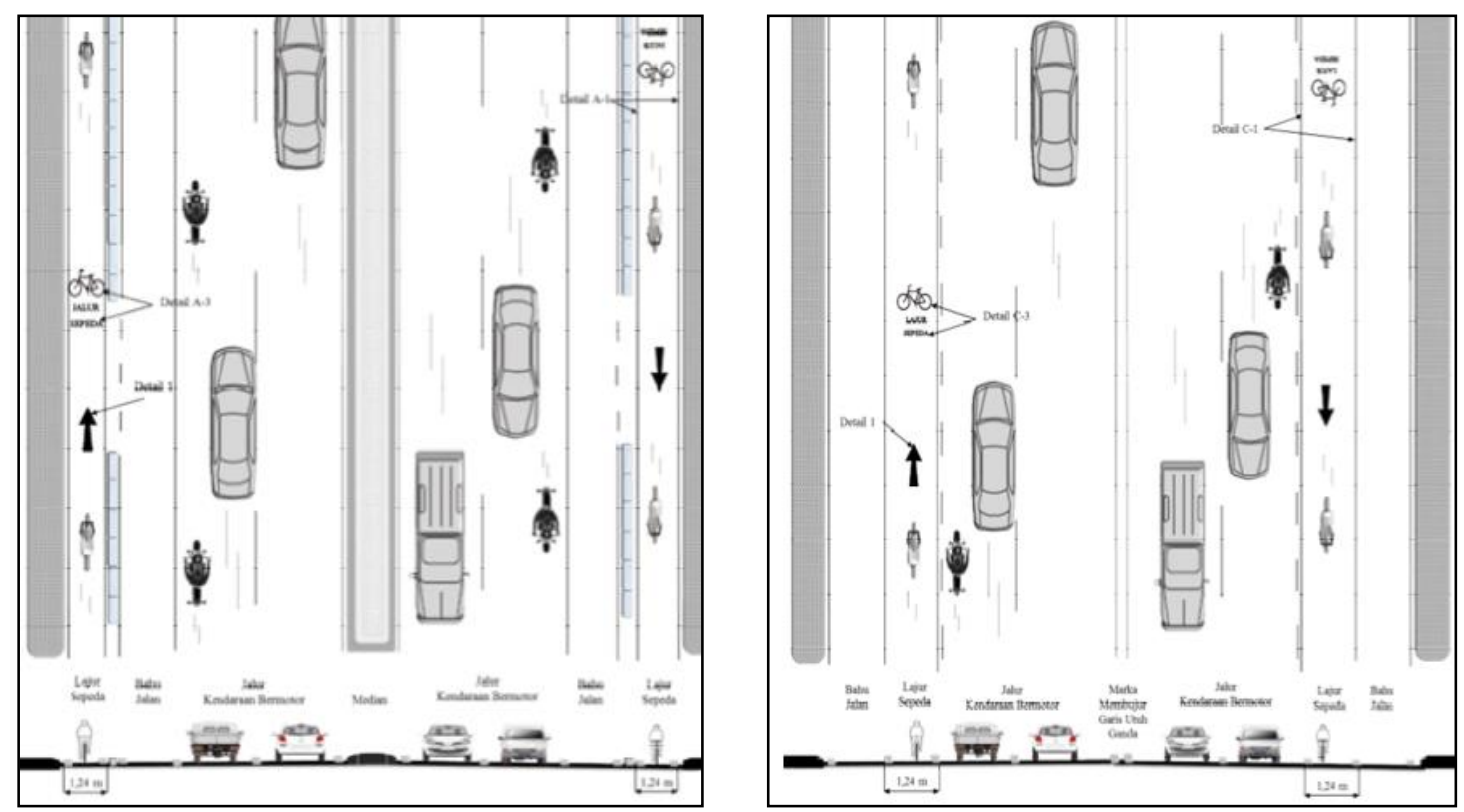

Figure 6. Type A Bike Lane (Left) and Type C Bike Lane (Right)
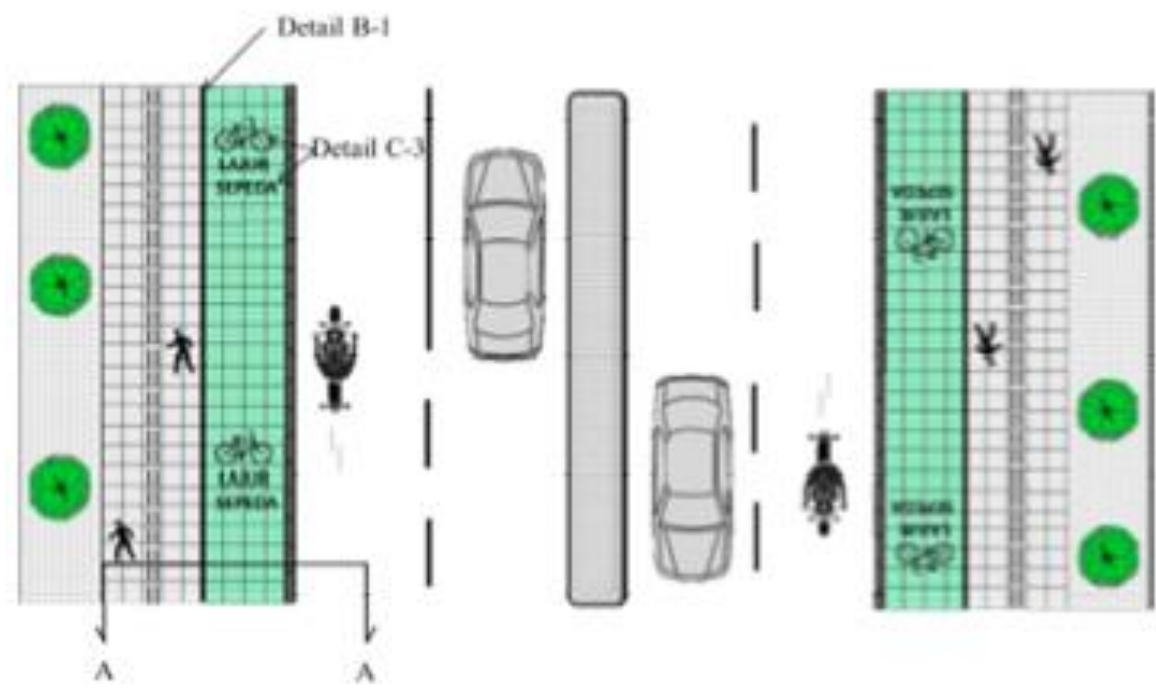

Figure 7. Type B Bike Lane

Table 5. Bike Lane Type A in Bandung City Roads

\begin{tabular}{clc}
\hline No & \multicolumn{1}{c}{ Street/Road Name } & Bike lane Type \\
\hline 1 & Jl. A. Yani & A \\
2 & Jl. BKR & A \\
3 & Jl. Buah Batu & A \\
4 & Jl. Cibeureum & A \\
5 & Jl. Cicendo & A \\
6 & Jl. Cimindi & A \\
7 & Jl. Dr. Junjunan & A \\
8 & Jl. Gardu jati & A \\
9 & Jl. Jamika & A \\
10 & Jl. Jend. Sudirman & A \\
11 & Jl. Laswi & A \\
\hline
\end{tabular}

\begin{tabular}{clc}
\hline No & \multicolumn{1}{c}{ Street/Road Name } & Bike lane Type \\
\hline 12 & Jl. Lengkong Besar & A \\
13 & Jl. Lengkong Kecil & A \\
14 & Jl. Otista & A \\
15 & Jl. Pajajaran & A \\
16 & Jl. Pasir Kaliki & A \\
17 & Jl. Pelajar Pejuang 45 & A \\
18 & Jl. Pungkur & A \\
19 & Jl. Raya Cimahi & A \\
20 & Jl. Sukajadi & A \\
21 & Jl. Terusan Tol & A \\
& Cileunyi & \\
\hline
\end{tabular}


Table 5. Bike Lane Type B in Bandung City Roads

\begin{tabular}{clc}
\hline No. & \multicolumn{1}{c}{ Street/Road Name } & Bike lane Type \\
\hline 1 & Jl. Ir. Haji Juanda & B \\
2 & Jl. R.A.A Martanegara & B \\
3 & Jl. Sunda & B \\
4 & Jl. Supratman & B \\
\hline
\end{tabular}

Table 6. Bike Lane Type C in Bandung City Roads

\begin{tabular}{clc}
\hline No & \multicolumn{1}{c}{ Street/Road Name } & Bike lane Type \\
\hline 1 & Jl. Banda & $\mathrm{C}$ \\
2 & Jl. Belitung & $\mathrm{C}$ \\
3 & Jl. Cendana & $\mathrm{C}$ \\
4 & Jl. Citarum & $\mathrm{C}$ \\
5 & Jl. Diponegoro & $\mathrm{C}$ \\
6 & Jl. Gurame & $\mathrm{C}$ \\
7 & Jl. K.H. Dahlan & $\mathrm{C}$ \\
8 & Jl. Kebon Kawung & $\mathrm{C}$ \\
9 & Jl. Leuwi Panjang & $\mathrm{C}$ \\
\hline
\end{tabular}

\begin{tabular}{clc}
\hline No & \multicolumn{1}{c}{ Street/Road Name } & Bike lane Type \\
\hline 10 & Jl. Surya Sumantri & C \\
11 & Jl. Sadakeling & $\mathrm{C}$ \\
12 & Jl. Sentot Ali Basyah & $\mathrm{C}$ \\
13 & Jl. Sukabumi & $\mathrm{C}$ \\
14 & Jl. Sumatera & $\mathrm{C}$ \\
15 & Jl. Tamansari & $\mathrm{C}$ \\
16 & Jl. Tamblong & $\mathrm{C}$ \\
17 & Jl. Turangga & $\mathrm{C}$ \\
\hline
\end{tabular}

Table 7. Roads in Bandung City Not Feasible for Bike Lanes

\begin{tabular}{|c|c|c|c|c|c|}
\hline No. & Street/Road Name & Bike lane Type & No. & Street/Road Name & Bike lane Type \\
\hline 1 & Jl. ABC & Not Feasible & 32 & Jl. Dipati Ukur & Not Feasible \\
\hline 2 & Jl. Abd. Raden Saleh & Not Feasible & & J1. Dr. Cipto & \\
\hline 3 & Jl. Abd. Rivai & Not Feasible & 33 & Mangunkusumo & Not Feasible \\
\hline 4 & Jl. Aceh & Not Feasible & 34 & Jl. Eijkman & Not Feasible \\
\hline 5 & Jl. Asia Afrika & Not Feasible & 35 & Jl. Elang & Not Feasible \\
\hline 6 & Jl. Banceuy & Not Feasible & 36 & Jl. Ganesa & Not Feasible \\
\hline 7 & Jl. Banda Cimandiri & Not Feasible & 37 & Jl. Gang 4 & Not Feasible \\
\hline 8 & Jl. Bojong Soang & Not Feasible & 38 & Jl. Garuda & Not Feasible \\
\hline 9 & Jl. Bp. Husen & Not Feasible & 39 & Jl. Gatot Subroto & Not Feasible \\
\hline 10 & Jl. Braga & Not Feasible & & Jl. Gatot Subroto & \\
\hline 11 & Jl. Burangrang & Not Feasible & 40 & (Cimahi) & Not Feasible \\
\hline 12 & Jl. Caringin & Not Feasible & 41 & Jl. Gede Bage & Not Feasible \\
\hline 13 & Jl. Cemara & Not Feasible & 42 & Jl. Gegerkalong Hilir & Not Feasible \\
\hline 14 & Jl. Cibeunying & Not Feasible & 43 & Jl. Gudang Utara & Not Feasible \\
\hline 15 & Jl. Cibolerang & Not Feasible & 44 & Jl. Holis & Not Feasible \\
\hline 16 & Jl. Cigondewah & Not Feasible & 45 & Jl. Ibu Inggit Ganarsih & Not Feasible \\
\hline 17 & Jl. Cihampelas & Not Feasible & 46 & Jl. Jakarta & Not Feasible \\
\hline 18 & Jl. Cijerah Raya & Not Feasible & 47 & Jl. Jawa & Not Feasible \\
\hline 19 & Jl. Cikawao & Not Feasible & 48 & Jl. Jurang & Not Feasible \\
\hline 20 & Jl. Cikutra & Not Feasible & 49 & Jl. Kalipah apo & Not Feasible \\
\hline 21 & Jl. Cileunyi & Not Feasible & 50 & Jl. Kapt. Tatanegara & Not Feasible \\
\hline 22 & Jl. Cipaganti & Not Feasible & 51 & Jl. Karang Sari & Not Feasible \\
\hline 23 & Jl. Ciroyom & Not Feasible & 52 & Jl. Karapitan & Not Feasible \\
\hline 24 & Jl. Cisaranten Kulon & Not Feasible & 53 & Jl. Katamso & Not Feasible \\
\hline 25 & Jl. Cisarua & Not Feasible & 54 & Jl. Kebon Jati & Not Feasible \\
\hline 26 & Jl. Ciserung & Not Feasible & 55 & Jl. Kopo & Not Feasible \\
\hline 27 & Jl. Ciumbeluit & Not Feasible & 56 & Jl. Kopo Sayati & Not Feasible \\
\hline 28 & Jl. Ciwastra & Not Feasible & 57 & Jl. Lembong & Not Feasible \\
\hline 29 & Jl. Dalem Kaum & Not Feasible & 58 & Jl. Leuwigajah & Not Feasible \\
\hline 30 & Jl. Derwati & Not Feasible & 59 & Jl. Lodaya & Not Feasible \\
\hline 31 & Jl. Dewi Sartika & Not Feasible & 60 & Jl. Lombok & Not Feasible \\
\hline
\end{tabular}




\begin{tabular}{lll}
\hline No. & \multicolumn{1}{c}{ Street/Road Name } & Bike lane Type \\
\hline 61 & Jl. Margacinta & Not Feasible \\
62 & Jl. Merdeka & Not Feasible \\
63 & Jl. Moh. Ramdan & Not Feasible \\
64 & Jl. Moh. Toha & Not Feasible \\
65 & Jl. Naripan & Not Feasible \\
66 & Jl. Pagarsih & Not Feasible \\
67 & Jl. Palasari & Not Feasible \\
68 & Jl. Pasir Koja & Not Feasible \\
69 & Jl. Pasteur & Not Feasible \\
70 & Jl. Perintis Kemerdekaan & Not Feasible \\
71 & Jl. Peta & Not Feasible \\
72 & Jl. PHH Mustofa & Not Feasible \\
73 & Jl. Prof. DR. Sutami & Not Feasible \\
74 & Jl. Purnawarman & Not Feasible \\
75 & Jl. Purwakarta & Not Feasible \\
76 & Jl. Rajawali Barat & Not Feasible \\
77 & Jl. Rajawali Timur & Not Feasible \\
78 & Jl. Raya Cibiru & Not Feasible \\
79 & Jl. Raya Cipadung & Not Feasible \\
80 & Jl. Raya Sumedang & Not Feasible \\
81 & Jl. Raya Ujung Berung & Not Feasible \\
82 & Jl. Rumah Sakit & Not Feasible \\
\hline
\end{tabular}

\begin{tabular}{cll}
\hline No. & \multicolumn{1}{c}{ Street/Road Name } & Bike lane Type \\
\hline 83 & Jl. Sancang & Not Feasible \\
84 & Jl. Sarijadi & Not Feasible \\
85 & Jl. Seram & Not Feasible \\
86 & Jl. Siliwangi & Not Feasible \\
87 & Jl. Sindang Laya & Not Feasible \\
88 & Jl. Sulanjana & Not Feasible \\
89 & Jl. Sumatra & Not Feasible \\
90 & Jl. Sumbawa & Not Feasible \\
91 & Jl. Suniaraja & Not Feasible \\
92 & Jl. Surapati & Not Feasible \\
93 & Jl. Telaga Bodas & Not Feasible \\
94 & Jl. Terusan Buah Batu & Not Feasible \\
95 & Jl. Terusan Holis & Not Feasible \\
96 & Jl. Terusan Jakarta & Not Feasible \\
& Jl. Terusan Jend Gt. & \\
97 & Subroto & Not Feasible \\
& Jl. Terusan Kiara & \\
98 & Condong & Not Feasible \\
& Jl. Terusan Prof. DR. & \\
99 & Sutami & Not Feasible \\
100 & Jl. Veteran & Not Feasible \\
101 & Jl. Wastu Kencana & Not Feasible \\
\hline
\end{tabular}

Table 8. Roads in Bandung City which are Not Continuously Feasible for Bike Lanes

\begin{tabular}{clc}
\hline No. & \multicolumn{1}{c}{ Street/Road Name } & Bike lane Type \\
\hline 1 & Jl. Astana Anyar & A to Not Feasible \\
2 & Jl. Cibadak & C to Not Feasible \\
3 & Jl. Cibaduyut & C to Not Feasible \\
4 & Jl. Kiara Condong & A to Not Feasible \\
5 & Jl. Pahlawan & C to Not Feasible \\
6 & Jl. R.E Martadinata & B to Not Feasible \\
7 & Jl. Setiabudi & A to Not Feasible \\
8 & Jl. Soekarno Hatta & A to Not Feasible \\
\hline
\end{tabular}

Table 9. Bike Lane Classification Resume

\begin{tabular}{cr}
\hline Bike lane Type & Total \\
\hline A & 21 \\
B & 4 \\
C & 17 \\
Not feasible for bike lane & 101 \\
Not continuously feasible & 8 \\
\hline
\end{tabular}

\section{CONCLUSION}

It seems that the type of bike lane is based on road width and sidewalk conditions. Apparently, roads/streets with planned bike lanes will require sufficient width and good conditions of the road or sidewalk. As a result, from 151 artery and collector roads in Bandung, only 42 of them met the requirements/standards for the bike lane facility.

Most of the roads in Bandung are not suitable for bike lanes although in main roads such as Jl. Ir. H. Juanda, Jl. Supratman, and Jl. Jend. A. Yani a bike lane is allowed to be built. Integrated with the bike lane plan of the bike sharing program, several numbers of 
roads/streets were not allowed to be built. Another study should look into possibility of $\mathrm{road} / \mathrm{street}$ widening and sidewalk rehabilitation to complement the design plan for a bike lane facility.

It is questionable how to adjust roads and streets in Bandung to meet the criteria of bike lane development. Due to limited land and the growing motor-vehicle traffic, bike lanes seem to become the last priority. A technical approach alone cannot make the bike lane program possible. Thus, a more humanly-inspired method can be supportive, such as greater promotion of bicycling and bike sharing programs and green transport campaign, etc.are recommended to improve the sustainability of the city environment.

\section{ACKNOWLEDGEMENTS}

We would like to thank Bandung City Government and Banopolis as the local consultant for bike sharing for their time and support in this study.

\section{REFERENCES}

AASHTO, (1998). Guide for the Development of Bicycle Facilities.

Bandung Statistic Data Center (2013). Bandung City. Retrieved from: http://bandungkota.bps.go.id/ (Accessed February 2015)

DeMaio, P. (2009). Bike-sharing: History, Impacts, Model of Provision, and Future. Journal of Public Transportation, Vol. 12, No. , 41-56.

Huang, H. F., Stewart, J. R., \& Zegeer, C. V. (2002). Evaluation of Lane Reduction "Road Diet" Measures on Crashes and Injuries. Transportation Research Record 1784, 8090.

ITDP. (2014). The Bike Share Planning Guide Institute for Transportation and Development Policy. New York: ITDP.

Kueper, D. (2007). Road Diet Treatment in Ocean City, NJ, USA. ITE Journal.

Ministry of Public Works (2013). Pedoman Perancangan Fasilitas Lajur dan Jalur Sepeda. Indonesia

Pennsylvania Department of Transportation and New Jersey Department of Transportation. (2008). Planning and Designing Highways and Streets that Support Sustainable and Livable Communities. Pennsylvania: Penndot and NJDOT.

Van Houten, R., \& Seiderman, C. (2005). How Pavement Markings Influence Bicycle and Motor Vehicle Positioning: A Case Study in Cambridge, MA. Transportation Research Board Annual Meeting. Cambridge: Transportation Research Board.

West Java Statistic Data Center (2004-2012). Bandung City. Retrieved from: http://jabar.bps.go.id/ (Accessed February 2015) 